\title{
Lifecycle Duration and Maturity Heterogeneity of Jatropha curcas Linn
}

\author{
Jupikely James Silip (Corresponding author) \\ School of Sustainable Agriculture, Universiti Malaysia Sabah \\ Locked Bag No.2073, 88999 Kota Kinabalu, Sabah, Malaysia \\ Tel: 60-1-9882-3023 E-mail: silip@ums.edu.my \\ Armansyah H. Tambunan
}

Laboratory of Agricultural Energy and Rural Electrification, Department of Agricultural Engineering Faculty of Agricultural Technology, Bogor Agricultural University, Bogor 16680, Indonesia

Tel: 62-81-3990-96367Ｅ-mail: ahtambun@ipb.ac.id

Herliza Hambali

Surfactant and Bioenergy Research Centre (SBRC), Jl. Raya Pajajaran No. 1, Bogor 16144, Indonesia

Tel: 62-81-115-7030 E-mail: erliza_h@sbrc-ipb.com

Sutrisno

Department of Agricultural Engineering, Faculty of Agricultural Technology

Bogor Agricultural University, Bogor 16880, Indonesia

Tel: 62-81-111-3143

Memen Surahman

Department of Agronomy and Horticulture, Faculty of Agriculture

Bogor Agricultural University Bogor16880, Indonesia

Tel: 62-81-2823-1160Ｅ-mail: memensurahman@yahoo.com

This research is financed by Institute of Agro-Biotechnology Malaysia, Ministry of Science and Technology Malaysia. (Sponsoring information)

\begin{abstract}
Jatropha is new oilseed crop and little is known about its reproductive characters. Therefore this study was conducted with the main objective to determine the lifecycle duration of Jatropha fruits from seeding to appearance of buds, fruit set, physiologically matured, ripening and senescence. To obtain more information on the fruit maturity, fruit maturity uniformity in seven local jatropha accessions was studied. During the study it was observed that Jatropha start to bear a flower after 90 to 120 days of seeding. The study also showed a wide variation in days to physiologically maturity of fruit, ripening and senescence. This crop showed indeterminate characteristics with fruits maturing at the bottom of the stem while buds developed at the top of the plants. Results of this study demonstrate that Jatropha is an indeterminate crop, which requires careful harvest and postharvest handling to increase harvestable fruits and therefore could reduce harvesting cost.
\end{abstract}

Keywords: Jatropha, Maturity, Indeterminate, Reproductive, Lifecycle

\section{Introduction}

Jatropha has been given a priority as the main source of biodiesel feedstock because other sources such as oil palm and soybean are edible oils. The potential use of Jatropha oil as biodiesel feedstock has been well studied (Augustus et al., 2002; Pramanik, 2003 and Reddy and Ramesh, 2006). The oil is comparable to diesel fuel, but its density and viscosity are much higher (Namasivayam et al., 2007). It was forecasted that each year for the next 5 to 7 years approximately 2 million hectares of Jatropha will be planted around the world (GEXSI, 2008). Because Jatropha is not a domesticated industrial crop, a lot of research on Jatropha has just started.

Poor harvesting has been the major retarding factor for commercialization of this crop and has been highlighted in many publications. Jatropha fruits mature heterogeneously which leads to laborious and time consuming harvesting because the fruit harvesters have to select only the fruits that are of the right ripening index for latter processing and have to be harvested manually at regular intervals (Heller, 1996 and Biswas et al., 2006). Mechanical harvesting of this crop was considered impossible due to this indeterminate flowering and growth habit. Today, Jatropha fruits are still harvested by hand in small and plantation scale farms. In permanent humid areas, weekly harvest in Jatropha field was required all year through but in dry areas harvest is recommended over a period of two months, which implies daily or weekly harvests. The indeterminate reproductive habit of Jatropha is thought to be related to this problem but little information exists on these characters.

Information on the number of male and female flowers in jatropha is well documented. The male flowers are more numerous reaching about $80-90 \%$ (Aker, 1997). The number of flowers (male plus female) in each 
inflorescence is around $66-159$ depending on ecotype (Santoso, 2008). The total number of female flowers does not guarantee complete fruit set. The phenophases in plants depends on the interaction between various phytohormones with the environment (Bruns, 2009). Time of harvesting after anthesis of this crop can vary from as early as 37 days (Annarao et al., 2008) to 90 days (Heller, 1996). Contrary recommendations on harvesting time based on days after anthesis is thought to be due to this non determinate growth habit of the crop.

Jatropha is a newly domesticated crop that is hampered by the abovementioned harvesting problems. Long term solutions could be the breeding of varieties whose growth habit are determinate with uniform fruit maturity. These traits can make harvest scheduling possible for maximum economic yield. Unfortunately, the breeding of new varieties is costly and time consuming and, therefore, near-term solutions are also needed during domestication of local accession. One of the solutions involves harvest and postharvest treatments. Physiologically mature fruit could be ripened off the tree with similar oil extraction quantity and quality as those ripening on the tree. Since the poor harvesting efficiency has been attributed to the indeterminate growth habit, this study focused on characterizing the indeterminate growth habit. This involved monitoring the lifecycle duration and maturity uniformity of the jatropha fruits.

\section{Materials and Methods}

\subsection{Source of Jatropha}

The lifecycle duration study was conducted from May to December 2009 at the Jatropha Plot belonging to Agro-Biotechnology Institute located at Luanti Baru Village Keningau, Sabah, Malaysia $\left(5^{\circ} 20^{\prime} \mathrm{N} / 116^{\circ} 10^{\prime} \mathrm{E}\right)$ on an Acrisol soil type. Sabah, Malaysia is characterized by a humid tropical climate which is moist and wet throughout the year with heavy rainfall $\left(2,500\right.$ to $5,000 \mathrm{~mm}$ p.a.), average daily temperatures of $21-32^{\circ} \mathrm{C}$ and humidity averaging about $85 \%$. Due to small seasonal variation in incoming solar radiation, the annual difference in daylength is only 2 minutes along the equator and 49 minutes in northern regions, giving a daylength of 12.30 hours year round (Nieuwolt 1982). Rainfall is affected by the North - East (November - March) and South - West (June-August) monsoons which result in heavy rainfall. For the months April-May and September-October, less rain is experienced because of changes in monsoonal winds. The plot was previously cropped with hill paddy but has been left idle for more than a year. A one hectare plot size was prepared by manual land clearing followed by minor open burning after the weeds were dried within two weeks of slashing. The seedlings were obtained from wild jatropha trees growing around the village. Only yellow and black fruits were collected, separated from fruit coat and dried under shade for three days. The seeds were directly planted onto the plot with a planting distance of $2 \times 2$ meters with two seeds per hole. No fertilizer was applied along the observation but weeds were controlled chemically with glyphosate (N-(phosphnomethyl)glycine) and hand weeding as needed especially for weeds around the crop stem.

To obtain information on the maturity uniformity characteristics of jatropha, data was collected on eight accessions at two jatropha pilot projects in the state. The pilot projects are Jatropha pilot project belonging to Sabah Department of Agriculture at Tenom Research Station and Jatropha pilot project belong to Sabah Land Development Board at Binakan Sook Keningau. Both pilot projects started first planting in March 2008. The data was collected at the end of March, 2009 when the trees were exactly one year old. The accessions were named based on where the seedlings were collected in the state. In this survey, only five trees were randomly selected for data collection because technically, counting the total fruits based on maturity stages is notoriously time consuming.

\subsection{Data Collection and Analysis}

To start determining the lifecycle duration, the date of planting was recorded (July 16, 2009). For the determination of bud development, flowering, fruit maturation, ripening and senescence duration, 30 trees were randomly tagged in the plot. After that one inflorescence on each of the tagged trees was also tagged which normally emanates from the main stem. The changes of the productive variables were recorded every day. Fruit maturity stages were predetermined as stage 1 (small young immature fruit), stage 2 (physiologically mature or mature green), stage 3 (half green and half yellow fruit coat), stage 4 (fully yellow fruit coat), stage 5 (half yellow and half black fruit coat), stage 6 (black wet fruit) and stage 7 (black dry fruit). Percentage of fruits according to the established maturity index was assessed by calculating the percentage number fruits of similar maturity from the total number of fruits on trees or bunches. The collected data was analyzed descriptively. Minimum, maximum and average days were summarized and described.

\section{Results and Discussion}

\subsection{Lifecycle duration of Jatropha}

The results showed that jatropha starts to bear flowers within 93 to 124 days after seeding (Table 1). First buds appear within 85 to 98 days after seeding and will develop to become flowers within 7 to 18 days. Flowering to fruit set occured within one to eight days. Fruits develop physiologically or reach mature green stage within 21 to 35 days from fruit set. Soon after physiological maturity, the fruits start to ripen or senesce which required 2 to 4 days to become fully yellow or fully ripe fruit and required 3 to 9 days to become fully black or fully senesced fruit. The results of this study indicate that the lifecycle of the local Luanti Jatropha accession planted at 
Agro-Biotechnology plot showed indeterminate growth habit. The fruit's lifecycle of this accession reached completion within a wide range of days (Table 1). The natural habit of Jatropha could be the reasons of high harvesting cost for this crop due to the fact that its fruit maturity, ripening and senescence were indeterminate. Furthermore, total harvestable fruit can be wrongly predicted due to this habit.

Today, most of industrial crops are classified as determinate crops. Therefore the management of these crops is easier and could be manipulated for maximum economic yield (Bruns, 2009). However, realistically crop development and or its maturation are affected by light, temperature changes and interactions with phytohormones. For example, well known determinate soybeans were reported to be only suitable for specific locations and its determinate habit changes into indeterminate habit if planted in other places (McWilliams et al., 2004). Therefore, efforts to find determinate jatropha accession should be done in the future.

\subsection{Maturity heterogeneity characteristics of Jatropha fruits}

Percentage of fruit according to predetermined maturity stages on whole tree and harvested bunches of seven selected Jatropha accessions was determined. The study showed that irrespective of accessions, the fruit maturity stages were not uniform (Fig. 1 and 2). Most of the fruits in whole trees were in maturity stage one and seven of about 50 and $10 \%$ respectively. The rest of the fruits were in maturity stage 2,3 and 4 . The high percentage of fruits at maturity stage one was expected because this stage includes the physiologically immature fruits or young fruits. On the other hand, majority of fruits in harvested bunches were in maturity stage 4 of more than 50\% (Fig. 2). High percentage of fruits at this maturity stage was expected because harvesters will only pick those bunches that have more ripe fruits or with less or no unripe fruits. It is impossible for harvesters to avoid unripe fruits during bunch harvesting compared to harvesting selective individual fruits.

This study corroborates reports by Biswas et al. (2006) and Heller (1996) that fruit ripening in this crop are not uniform on the tree and also in an individual harvested bunch (Silip and Tambunan 2008). With these maturity heterogeneity characters we confirm that none of the accessions in this study could be considered as determinate jatropha accession. The whole of the accessions showed that fruits mature at the bottom of the stem or branches while young immature fruit bunches and or flower or new buds were developing at the top of the plant. Determinate and indeterminate characters are described clearly by Berti et al. (2008) in cuphea crop and soybean (Bruns, 2009).

If this natural phenomenon is taken into account for the argument relating to harvesting recommendation, we believe that more information is still required for practical harvesting and post-harvest handling recommendations. Our interest on the harvesting recommendation of bunches will deal with physiological mature fruits, fully ripened, and senesced fruits. Physiologically mature fruits might require sorting and postharvest ripening treatments. However no such treatment is available in the current literature for Jatropha. In addition, recommendations on which ripening index that could give high oil quantity and quality are still not clear. It is also important to note that there are physiological and biochemical differences between fruits attached on and off the tree. According to Wills et al., (1989) the development and maturation of fruit is completed only when it is attached to the plant, but ripening and senescence may proceed on or off the plant. Therefore, this study opens up many future research possibilities in the area of postharvest physiology and technology.

\section{Conclusion and Recommendation}

Lifecycle and maturity characteristics of jatropha in this study indicated that all accessions used in this research are indeterminate types. Thus, harvesting is expected to become a major problem because wide ranging maturity and heterogeneity is expected to result in difficulties in harvesting schedule. The harvestable fruits prediction could also be inaccurate due to the wide variation in lifecycle duration. Future research should focus on identification of determinate accessions or new hybrids. On the other hand optimizing indeterminate characters to increase harvestable fruits could also be possible if physiologically mature fruits can be ripened off the tree. Therefore, this study indicates the necessity of more research in the near future.

\section{References}

Aker, C. L. (1997). Growth performance of J. curcas. In:Biofuels and industrial production from Jatropha curcas. Gurbitz, G. M., Mittelbach, M. and Trabi, M. (Eds). Pp.2-18, DBV Graz.

Annarao, S., Sidhu, O. P., Roy, R., Tuli, R. and Khetrapal, C. L. (2008). Lipid profiling of developing Jatropha curcas L. seeds using 1H NMR spectroscopy. Bioresource Technology.99: 9032-9035. www.elsevier.com/locate/biotech. Accessed on 22 November 2008.

Arteca, R. N. (1996). Plant growth substances principles and applications. Chapman and Hall, New York. Pp. 165. Augustus, G. D. P. S., Jayabalan, M. and Seiler G. J. (2002). Evaluation and bioinduction of energy components of Jatropha curcas. Biomass and Bioenergy 23:161-164.

Berti, M. T., Johnson, B. L., Gecsh, R. W. and Forcella, F. (2008). Cuphea seed yield response to harvest methods applied on different dates. American Journal of Agronomy 100(4):1138-1144.

Biswas, S., Kaushik, N. and Srikanth, G. (2006). Biodiesel: technology and business opportunities - an insight. In: Singh, B., Sawaminthan, R., Ponraj, V. editors. Proceedings of the biodiesel conference towards energy 
independence - focun on Jatropha. Hyderabad, India, Jun 9 - 10. New Delhi: Rashtrapati Bahwan. (2006). p. 303-330. cited from Achten, W. M. J., Verchot, L., Franken, J. Y., Mathijs, E., Singh, V. P., Aerts, R. and Muys, B. 2008. jatropha bio-diesel production and use. Biomass and Bioenergy.

Bruns, H. A. (2009). A survey of factor involved in crop maturity. Agronomy Journal, 101 (1):60-66.

GEXSI (Global Exchange for Social Investment). (2008). Global market study on Jatropha. London/Berlin, May $8^{\text {th }}, 2008$.

Heller, J. (1996). Physic nut. Jatropha curcas L. Promoting the conservation and use of underutilized and neglected crops. 1. PhD dissertation, Institute of Plant Genetic and Crop Plant Research, Getersleben, Germany, and International Plant Genetic Resource Institut, Rome, Italy, 1996. http:// www. ipgri. cigar.org/Publication/pdf/161.pdf.

McWilliams, D. A., Berland, D. A. and Endres, G. J. (2004). Soybean growth and management quick guide. Available at http://www.ag.ndsu.edu/pubs/plantsci/rowcrops /a1174/a1174w.htm. North Dakota State Univ. Fargo.

Namasivayam, C., Sangeetha, D. and Gunasekaran, R. (2007). Removal of anions, heavy metals, organic and dyes from water by adsorption into a new activated carbon from Jatropha husk, an agro-industrial solid waste. Process Safety and Environmental Protection 85:181-184.

Nieuwolt, S. (1982). Climate and agricultural planning in Peninsular Malaysia. MARDI Special Report No. ASAS-01-83. pp. 141.

Pramanik, K. (2003). Properties and use of jatropha curcas oil and diesel fuel blends in compression ignition engine. Renewable Energy 28:239-248.

Reddy, J. N. and Ramesh, A. (2006). Parametric studies for improving the performance of a Jatropha oil-fuelled compression ignition engine. Renewable Energy 31:1994-2016.

Santoso, B. B. (2008). Karakterisasi Morfologi dan Agronomi serta Kandungan Minyak Jarak Pagar (Jatropha curcas L.). PhD Thesis. Bogor Agricultural University.

Silip, J. J. and Tambunan A. H. (2008). Physical Postharvest Characteristics at Harvest of Jatropha curcas L. Lokakarya National IV Jarak Pagar, Malang, Surabaya, November 6, 2008.

Wills, R. T., Graham, D., McGlasson, W. B. and Joyce, D. (1998). Postharvest: An introduction to the physiology and handling of fruit, vegetables and ornamentals. $4^{\text {th }}$ Ed. Sydney: UNSW Press Ltd.

Table 1. Lifecycle duration or days required by Jatropha curcas Linn vegetative and or reproductive variables: growth or changes from seeding, appearance of buds to fruit developing physiological maturity, ripening and senescence.

\begin{tabular}{|c|c|c|c|}
\hline \multirow{2}{*}{ Reproductive variables } & \multicolumn{3}{|c|}{ Days } \\
\cline { 2 - 4 } & Min. & Max. & Average \\
\hline Seeding to first appearance of bud & 85 & 98 & 91.5 \\
\hline Bud development & 7 & 18 & 12.5 \\
\hline Flowering to fruit set & 1 & 8 & 4.5 \\
\hline Fruit set to physiological mature fruit or mature green & 21 & 35 & 28 \\
\hline Mature green to yellow fruit & 2 & 4 & 3 \\
\hline Mature green to black fruit & 3 & 9 & 6 \\
\hline Mature green to dry fruit & 6 & 17 & 11.5 \\
\hline Flower to yellow fruit & 24 & 47 & 35.5 \\
\hline Flower to black fruit & 27 & 56 & 41.5 \\
\hline Flower to dry fruit & 36 & 73 & 54.5 \\
\hline
\end{tabular}




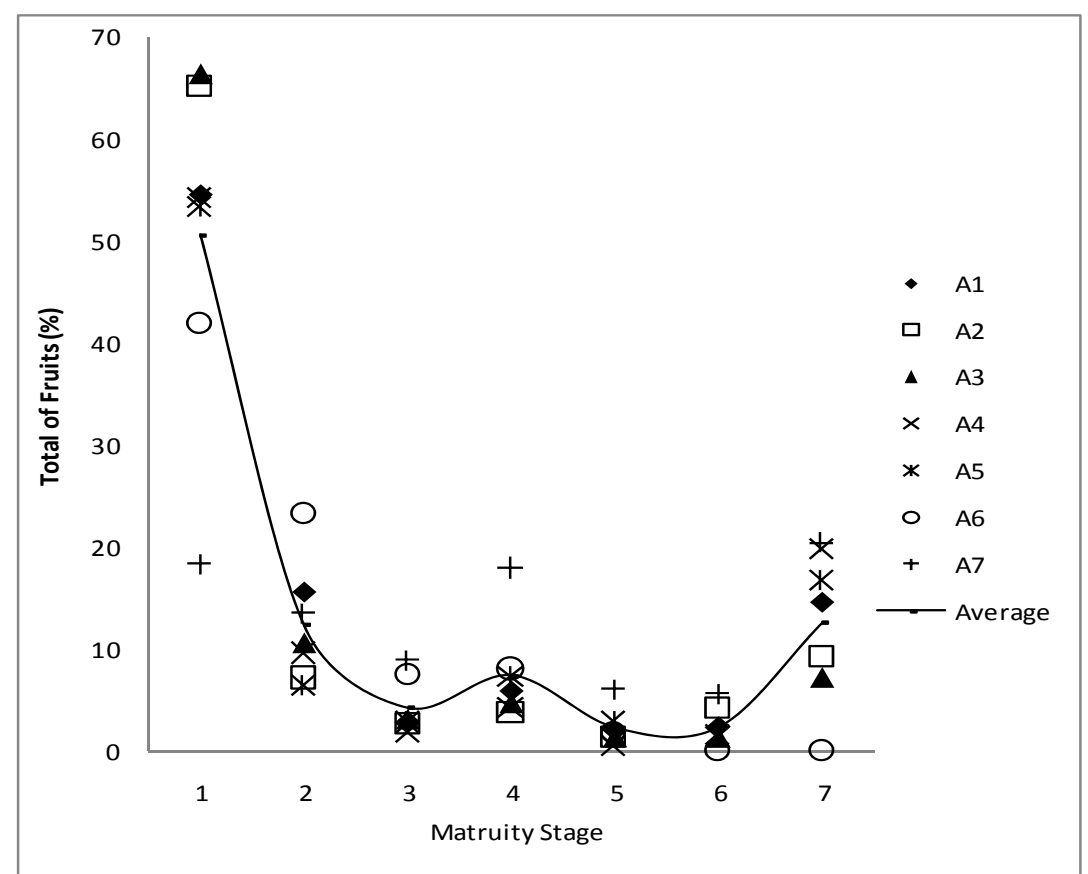

Figure 1. Percentage of fruits in a single tree according to maturity stages of eight local jatropha accessions in Sabah State of Malaysia. Solid line indicates the average of fruits. ( $\mathrm{n}=35)$.

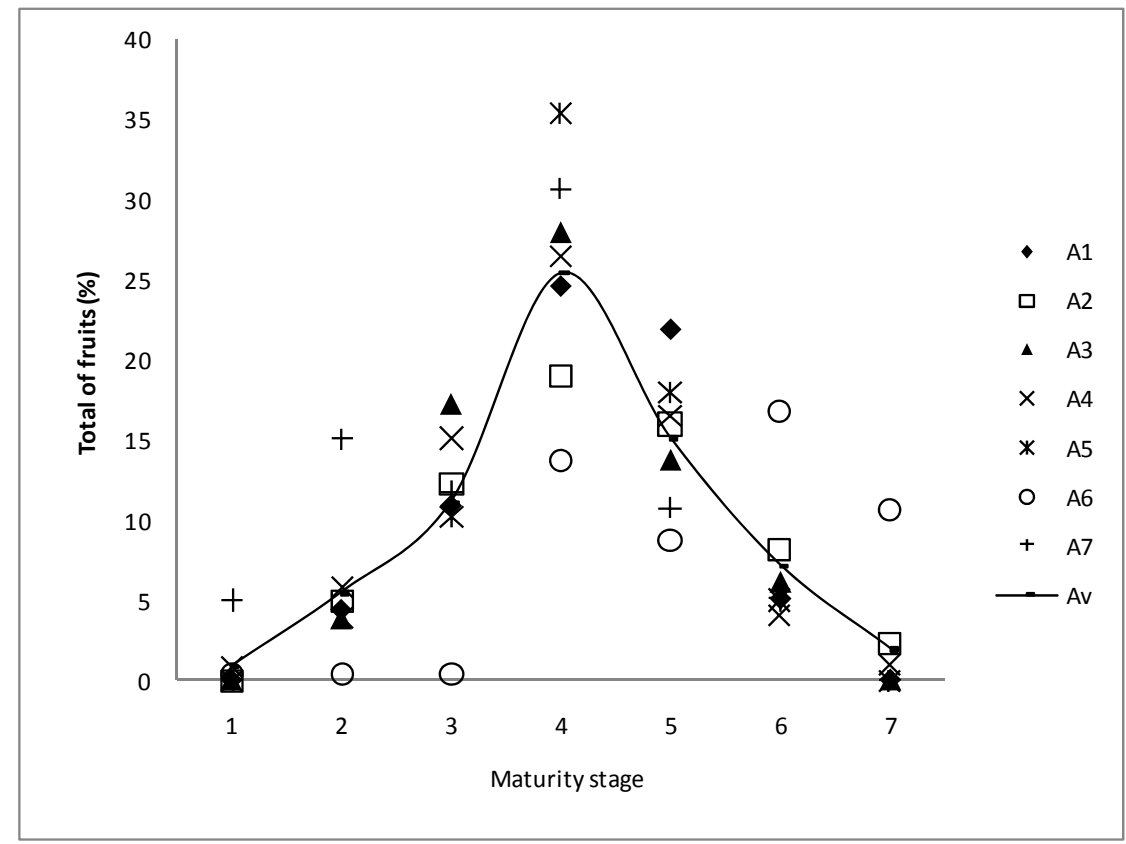

Figure 2. Percentage of fruits in harvested bunches according to maturity stages of eight local jatropha accessions in Sabah State of Malaysia. Solid line indicates the average of fruits. $(n=35)$. 